\title{
Характеристики та принципи регулювання роботи елементів малої системи тригенерації в умовах тропічного клімату
}

\author{
А. С. Денисова ${ }^{1}$, Л. І. Морозюк ${ }^{2}$, Альхемірі Саад Альдін ${ }^{1}$, Г. В. Лужсанська \\ ${ }_{1}^{1}$ Одеський національний політехнічний університет, пр. Шевченка, 1, Одеса, 65044, Україна \\ ${ }^{2}$ Одеська національна академія харчових технологій, вул. Канатна, 112, Одеса, 65039, Україна
}

\begin{abstract}
Розглянуто характеристики елементів малої системи тригенерації та алгоритм регулювання роботи системи в умовах тропічного клімату. Система вкючає енергетичну установку з прямим перетворенням сонячної енергї̈ в електричну, холодильну компресорну машину для кондиціювання та опалення житлового приміщення та активну систему вентиляиії для ичиркуляиії свіжого, обробленого повітря через приміщення. Дослідження показало, щуо система здатна вирішувати енергетичні, екологічні та соціальні проблеми населення, щзо проживає на територіях в умовах тропічного та різко континентального клімату.
\end{abstract}

Ключові слова: тригенерачія, компресорна холодильна машина, кондиціювання, опалення, регулювання роботи системи, тропічний клімат.

(C) The Author(s) 2018. This article is an open access publication

This work is licensed under the Creative Commons Attribution 4.0 International License (CC BY) http://creativecommons.org/licenses/by/4.0/

\section{1. Вступ}

Тригенерація являє собою інтегровану енергоперетворювальну систему, яка включає енергетичну установку, холодильну машину та установку отримання тепла. Два останні ефекти можна реалізувати як в різних машинах, так і єдиній, Об'єднує всі ефекти споживач, який отримує послугу від системи. Споживачем може бути технологічний процес в промисловому або сільськогосподарському виробництві. Споживачами можуть бути люди, які створюють в житловому приміщенні комфортні умови існування (автономне енергозабезпечення, опалення та кондиціювання). Основою для створення системи тригенерації малої енергетики $є$ економія паливних ресурсів в енергетичній установці та енергетичних - в машинах виробництва холоду та тепла.

В традиційних паливних енергетичних установках здійснюється утилізація теплових викидів для отримання тепла та холоду, Для холодопостачання передбачають тепловикористальні холодильні машини $[1,2]$.

В системах тригенерації з енергетичними установками на відновлювальних джерелах тепла та прямим перетворенням первинної енергії в електричну економію пов'язують 3 виробництвом тепла та холоду високоефективними паровими компресорними машинами [3]. Максимальний екологічний, економічний та соціальний ефект може бути отриманим за використанням сонячної фотоелектричної енергетичної установки 3 цілорічним повним навантаженням на електроенергію, зі змінним постійним споживанням холоду та тепла, що визначається кліматичними умовами місцевості, для якої призначена система тригенерації. Таким умовам відповідають території Північної Африки та Близького Сходу з тропічним та різко континентальним кліматом $[4,5]$. Аналіз кліматичних характеристистик зроблено 3 використанням даних інформаційного порталу [6]. Встановлено великі значення сонячної енергетичної освітленості на протязі року, значні зміни температур навколишнього середовищ від $45^{\circ} \mathrm{C}$ влітку до $-10{ }^{\circ} \mathrm{C}$ взимку та різкі коливання температур в денні та нічні часи від 10 до 40 градусів в різні сезони року. Як свідчать медики, коливання температур мають великий негативний вплив на здоров'я людей і являють собою джерело епідемічних захворювань.

Отже, цілорічне кондиціювання та опалення є головними об'єктами реалізації в системах тригенерації для жителів країн в жарким сухим кліматом. Розвиток та розширення дослідження характеристик елементів системи тригенерації $\epsilon$ актуальною науковою та практичною задачею, вирішення якої забезпечує енергозаощадження та екологічну безпеку для споживача.

\section{2. Математичне моделювання характеристик елементів блоку тепло-холодопостачання ма- лої системи тригенерації}

Для створення математичної моделі складної системи необхідно знати характеристики окремих елементів, що представляють собою залежності, які пов'язують вихідні параметри елементів з умовами роботи системи та конструктивними параметрами цих елементів. Основою математичної моделі в роботі $є$ рівняння, які описують процеси та залежності в елементах, та балансні рівняння для розрахунку машини в цілому.

Технологічна схема системи тригенерації, єлементи якої досліджуються в роботі, розроблена та термодинамічно обгрунтована можливість ії практичної реалізації в роботі авторів [7]. Система містить автономну сонячну фотоелектричну установку, холодильну машину, активну вентиляцію та споживача - приватний житловий будинок (приміщення). Взаємодія елементів становить таке. Споживач використовує цілорічно три енергетичні ефекти. Сонячна установка 3 прямим перетворенням енергії в електричну забезпечує освітлення, роботу електричних приладів, роботу компресора холо- 
дильної машини та роботу вентилятора системи вентиляції. Холодильна машина в залежності від температури навколишнього середовища здійснює холодильний або теплонасосний цикл. Система активної вентиляції свіже повітря, охолоджене або підігріте, доставляє в приміщення, забезпечуючи комфортну температуру за будь-якої температури навколишнього середовища.
Енергетичний баланс системи та температурні режими в приміщенні регулюються напрямками руху повітря та зміною продуктивності холодильної машини відповідно до зміни теплового навантаження (позитивного або негативного) на приміщення. Схема руху потоків в режимі кондиціювання представлена на рисунку 1.

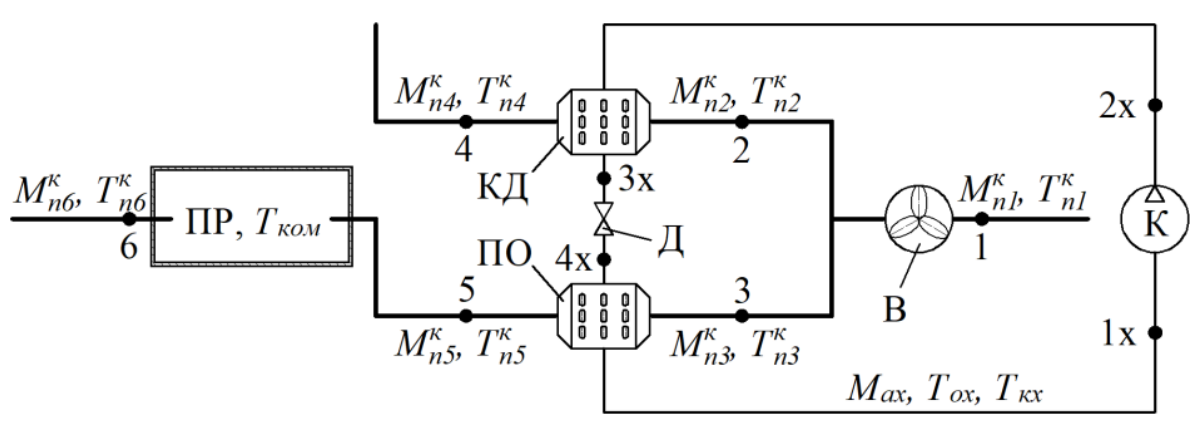

Рисунок 1 - Схема рухів потоків робочої речовини та повітря в режимі кондиціювання: К - компресор, КД - конденсатор, ПО - повітроохолоджувач, Д - дросельний пристрій, В - вентилятор, ПР - приміщення.

Загальний потік свіжого повітря з масовою витратою $M_{n 1}^{\kappa}$ та температурою $T_{n 1}^{\kappa}$ вентилятором В подається в систему вентиляції і розподіляється на два напрями: до конденсатора КД з масовою витратою $M_{n 2}^{\kappa}$ та повітроохолоджувача ПО з масовою витратою $M_{n 3}^{\kappa}$. Охолоджене повітря з температурою $T_{n 5}^{\kappa}$ після ПО надходить через припливну лінію в приміщення ПР, здійснює ефект охолодження і $з$ температурою $T_{n 6}^{\kappa}$ виходить через витяжну лінію в навколишнє середовище. У той же час другий потік проходить через конденсатор КД, відводить тепло конденсації і з температурою $T_{n 4}^{\kappa}$ виходить в навколишнє середовище. Робоча речовина з масовою витратою $M_{a}^{\kappa}$ здійснює холодильний цикл в інтервалі температур кипіння $T_{o}^{\kappa}$ та конденсації $T_{\kappa}^{\kappa}$.

Схема руху потоків в режимі опалювання представлена на рисунку 2.

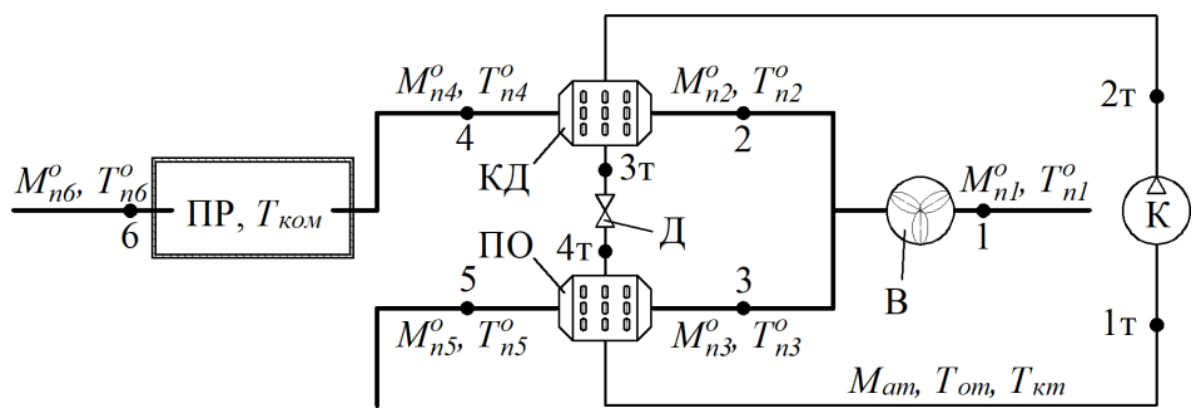

Рисунок 2 - Схема рухів потоків робочої речовини та повітря в режимі опалювання:

К - компресор, КД - конденсатор, ПО - повітроохолоджувач,

Д - дросельний пристрій, В - вентилятор, ПР - приміщення.

Загальний потік свіжого повітря з масовою витратою $M_{n 1}^{o}$ та температурою $T_{n 1}^{o}$ вентилятором В подається в систему вентиляції і розподіляється до конденсатора КД з масовою витратою $M_{n 2}^{o}$ та повітроохолоджувача ПО з масовою витратою $M_{n 3}^{o}$. Підігріте повітря після КД з температурою $T_{n 4}^{o}$ надходить через припливну лінію в приміщення ПР, здійснює ефект опалювання і з температурою $T_{n 6}^{o}$ виходить через витяжну лінію в навколишнє середовище. Потік повітря в повітроохолоджувачі здійснює теплообмін з киплячою робо- чою речовиною і охолоджений 3 температурою $T_{n 4}^{o}$ виходить в навколишнє середовище. Робоча речовина 3 масовою витратою $M_{a m}$ здійснює теплонасосний цикл в інтервалі температур кипіння $T_{\text {от }}$ та конденсації $T_{\kappa m}$.

Холодильна машина працює в двох режимах. Цикли холодильний $\left(1_{\mathrm{x}} 2_{\mathrm{x}} 3_{\mathrm{x}} 4_{\mathrm{x}}\right)$ та теплонасосний $\left(1_{\mathrm{T}} 2_{\mathrm{T}} 3_{\mathrm{T}} 4_{\mathrm{x}}\right)$ представлені в єдиній діаграмі $p$ - $h$ на рисунку 3 . Вибір робочої речовини на даному етапі дослідження вільний, аналіз циклів здійснюється на рівні температур. Можливий інтервал реалізованих температур кипіння $T_{o}^{\kappa} \ldots T_{o}^{o}$ становить від $-5{ }^{\circ} \mathrm{C}$ до $15^{\circ} \mathrm{C}$ та інтервал температур 
конденсації $T_{\kappa}^{\kappa} \ldots T_{\kappa}^{o}$. відповідно. від $30{ }^{\circ} \mathrm{C}$ до $50{ }^{\circ} \mathrm{C}$ [7]. Максимальна розрахункова температура навколишнього повітря для роботи конденсатора становить $T^{\kappa}{ }_{n 1}=40^{\circ} \mathrm{C}$. мінімальна для повітроохолоджувача $T_{n 1}^{0}=5^{\circ} \mathrm{C}$. Наведені значення відповідають середнім літнім та денним, зимовим та нічним температурам навколишнього середовища протягом року за інформацією [6] для території, яка досліджується. Мінімальна температура конденсації $T_{\kappa}^{o}$ та максимальна температура кипіння $T_{o}^{\kappa}$ пов'язані з комфортною температурою в приміщенні $T_{\text {ком }}=23{ }^{\circ} \mathrm{C}$, яка залишається постійною незалежно від температури навколишнього середовища.

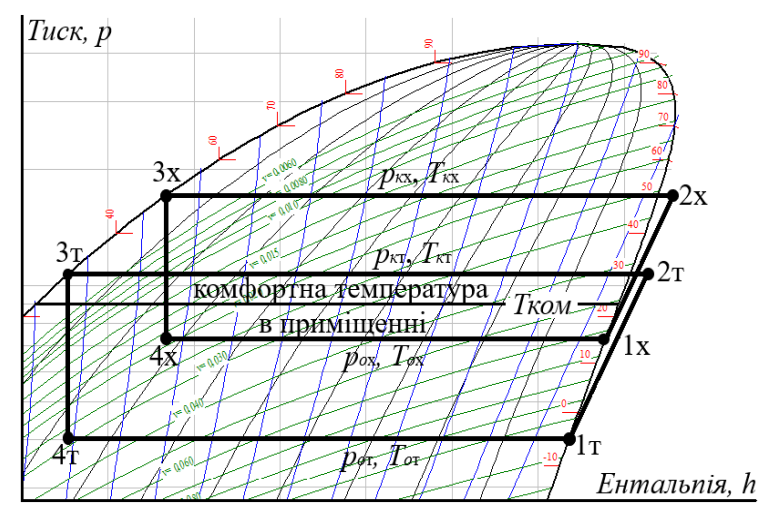

Рисунок 3 - Цикли холодильної машини в режимах кондиціювання та опалення

Характеристиками елементів є: теплове навантаження на приміщення в режимі кондиціювання $Q_{n p}^{\kappa}$, теплові втрати з приміщення в режимі опалення $Q_{n p}^{o}$, холодопродуктивність машини $Q_{o}^{\kappa}$ та ефективна потужність компресора $N_{e}^{\kappa}$ в режимі кондиціювання, теплове навантаження на конденсатор $Q_{\kappa}^{o}$ та ефективна потужність $N_{e}^{o}$ в режимі опалювання.

Характеристики компресора, які є функціями температури кипіння та конденсації для конкретної робочої речовини, розраховують на основі циклів 3 різними температурами конденсації та кипіння за математичними рівняннями [8]

$$
\begin{gathered}
Q_{o}=V_{h} \lambda q_{o} / v_{B c}=M_{a} q_{o}, \\
N_{e}=V_{h} \lambda w / v_{b c}=M_{a} w, \\
Q_{\kappa}=V_{h} \lambda q_{\kappa} / v_{B c}=M_{a} q_{\kappa}=Q_{o}+N_{e},
\end{gathered}
$$

де $V_{h}$ - теоретична об'ємна продуктивність компресора, $\lambda$ - коефіцієнт подавання, $v_{в c}-$ питомий об'єм робочої речовини на всмоктуванні компресора, $q_{o}, q_{\kappa}, w$ - питомі масові характеристики циклу.

Теоретичну об'ємну продуктивність компресора $V_{h}$ визначають за каталогами фірм-виробників.

Характеристику $Q_{o}$ в температурному інтервалі циклів наведено на рисунку 4 у вигляді множини кри- вих в залежності від температури кипіння. Кожній 3 кривих відповідає постійна температура конденсації.

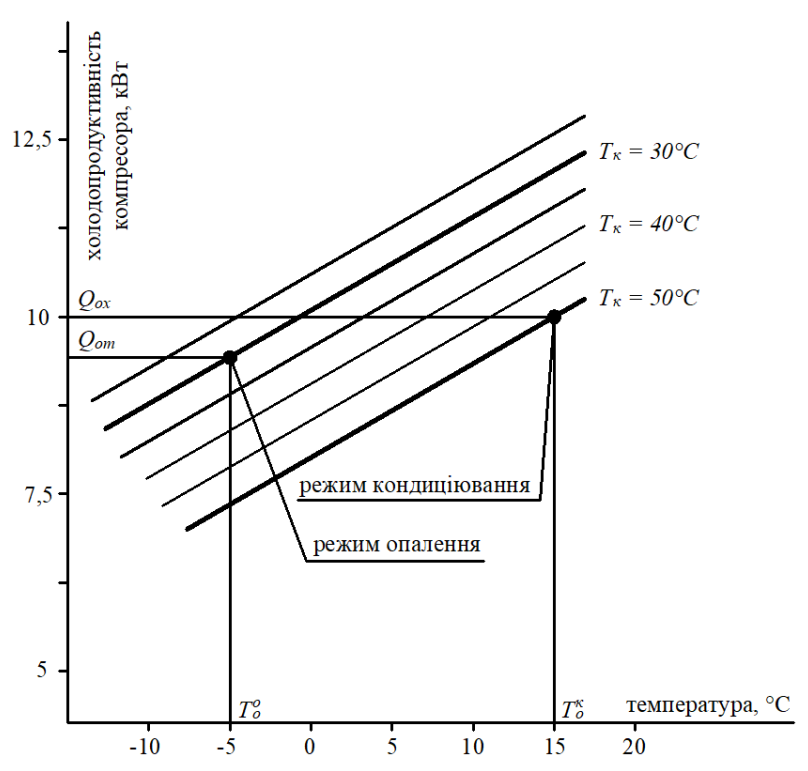

Рисунок 4 - Залежність $Q_{o}=f\left(T_{o}, T_{\kappa}\right)$

Для аналізу роботи машини в режимі теплового насосу характеристику $Q_{\kappa}$ компресора надають в залежності від температури конденсації з фіксацією температури кипіння (рисунок 5).

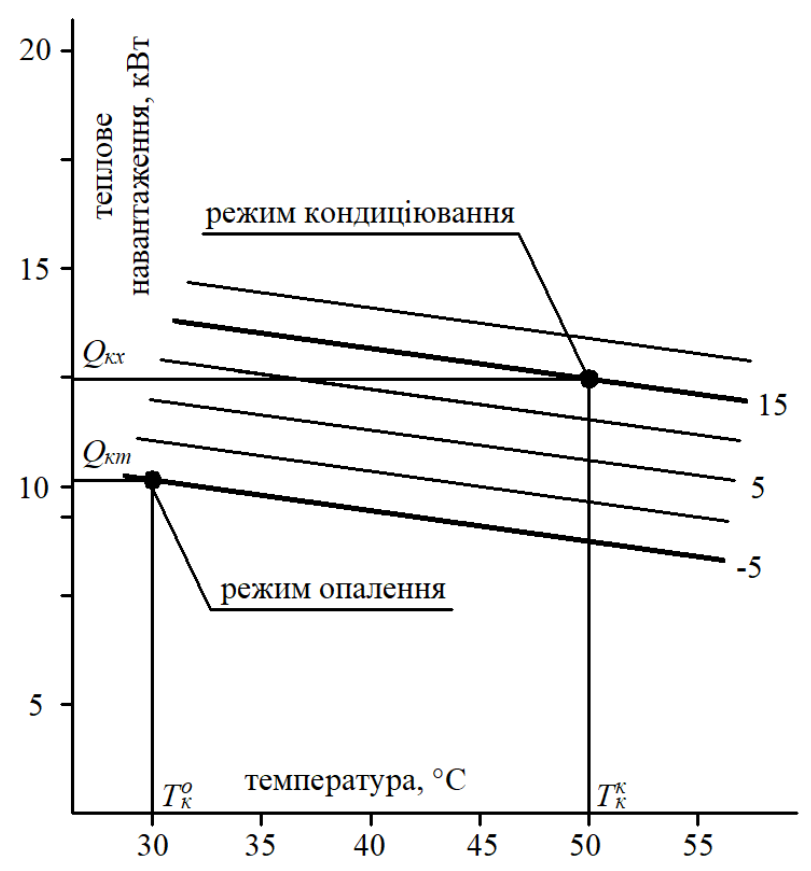

Рисунок 5 - Залежність $Q_{\kappa}=f\left(T_{\kappa}, T_{o}\right)$

Характеристики теплообмінних апаратів описано основним рівнянням теплопередавання [9]. Для повітроохолоджувача воно має вигляд:

$$
Q_{o}^{n o}=k_{i}^{n o} F_{i}^{n o}\left(T_{\text {ком }}-T_{o}\right)=k_{i}^{n o} F_{i}^{n o} \theta_{m}^{n o},
$$

де індекс «i» визначає розрахункову теплопередавальну поверхню. 
В конкретній конструкції повітроохолоджувача при постійній швидкості повітря $w_{1}$ теплопроходимість $\left(k_{i}^{n o} F_{i}^{n o}\right)$ можна приймати постійною. Тоді характеристика повітроохолоджувача в системі координат $Q-T$ зображена променем з початком на вісі абсцис 3 координатою $T_{\text {ком }}$ під кутом $\alpha$ (рисунок 5)

$$
\operatorname{tg} \alpha=Q_{o}^{n o} / \theta_{m}^{n o}=\left(\mu_{Q} / \mu_{T}\right) k_{i}^{n o} F_{i}^{n o},
$$

де $\mu_{Q}, \mu_{T}-$ відповідні масштаби.

При зміні швидкості та постійній температурі повітря в приміщенні хактеристика має вигляд множини променів, які виходять з однієї точки. При зміні температури та постійній швидкості характеристику надано множиною паралельних променів.

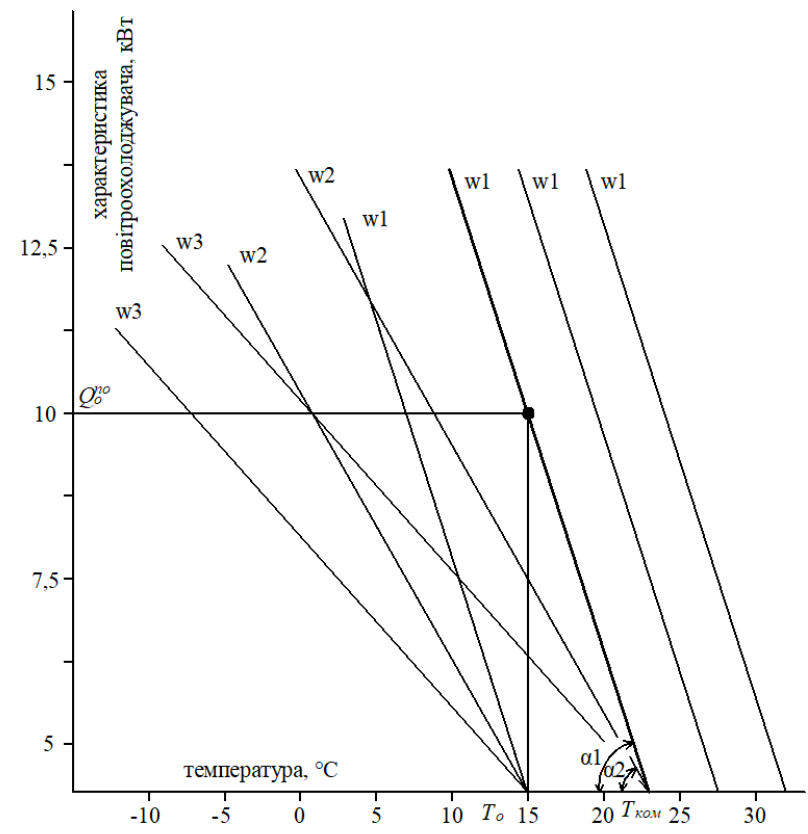

Рисунок 6 - Характеристика повітроохолоджувача

Характеристику конденсатора описано подібно до повітроохолоджувача:

$$
\begin{gathered}
Q_{\kappa}^{\kappa \partial}=k_{i}^{\kappa \partial} F_{i}^{\kappa \partial}\left(T_{\kappa}-T_{\kappa о м}\right)=k_{i}^{\kappa \partial} F_{i}^{\kappa \partial} \theta_{m}^{\kappa \partial}, \\
\operatorname{tg} \beta=Q_{\kappa}^{\kappa \partial} / \theta_{m}^{\kappa \partial}=\left(\mu_{Q} / \mu_{T}\right) k_{i}^{\kappa \partial} F_{i}^{\kappa \partial} .
\end{gathered}
$$

На рисунку 7 надано графічну інтерпретацію характеристики конденсатора.

Як свідчить аналіз, кожний 3 елементів машини має власні характеристики, які вказують на взаємозалежність різних параметрів цих елементів.

Температурний режим роботи системи тепло- холодопостачання, який змінюється навіть при постійній температурі в житловому приміщенні, залежить від температури навколишнього повітря, характеру процесу охолодження або опалення, нерівномірності теплового навантаження житлового приміщення та інших факторів. Зміна температурного режиму порушує відповідність між характеристиками елементів. Однак рівновагу можна встановити по досягненню режиму, який відповідає новим умовам.

Характеристиками житлового приміщення є теплоприпливи в жаркі сезони року та денні часи доби, тепловтрати в холодні сезони та нічні часи доби. Зі зниженням температури навколишнього повітря теплоприпливи зменшуються доки не наступить рівність температур зовні та всередині приміщення.

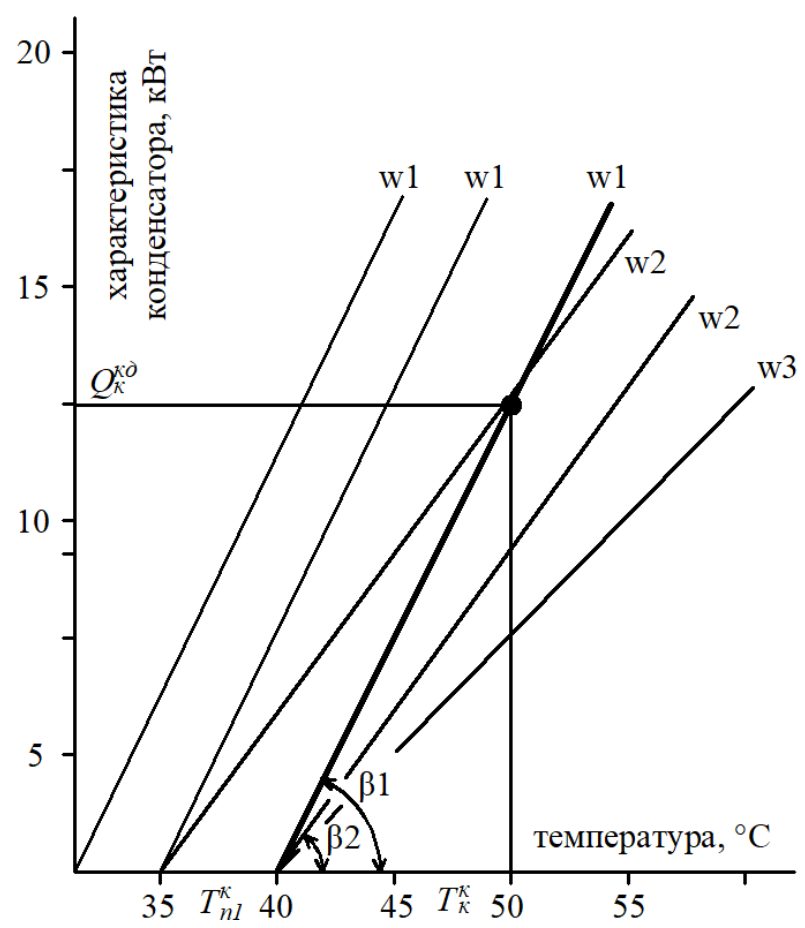

Рисунок 7 - Характеристика конденсатора

3 подальшим зниженням температури навколишнього повітря зростають тепловтрати. Теплоприпливи та тепловтрати в моделі обмежуються температурами навколишнього повітря, які прийнято у якості вихідного параметру для системи. Для прикладу, абсолютні значення теплових навантажень на приміщення прийняті до 10 кВт, що відповідає середньостатистичним значенням для приватних будинків [9]. В графічному вигляді характеристику надано на рисунку 8.

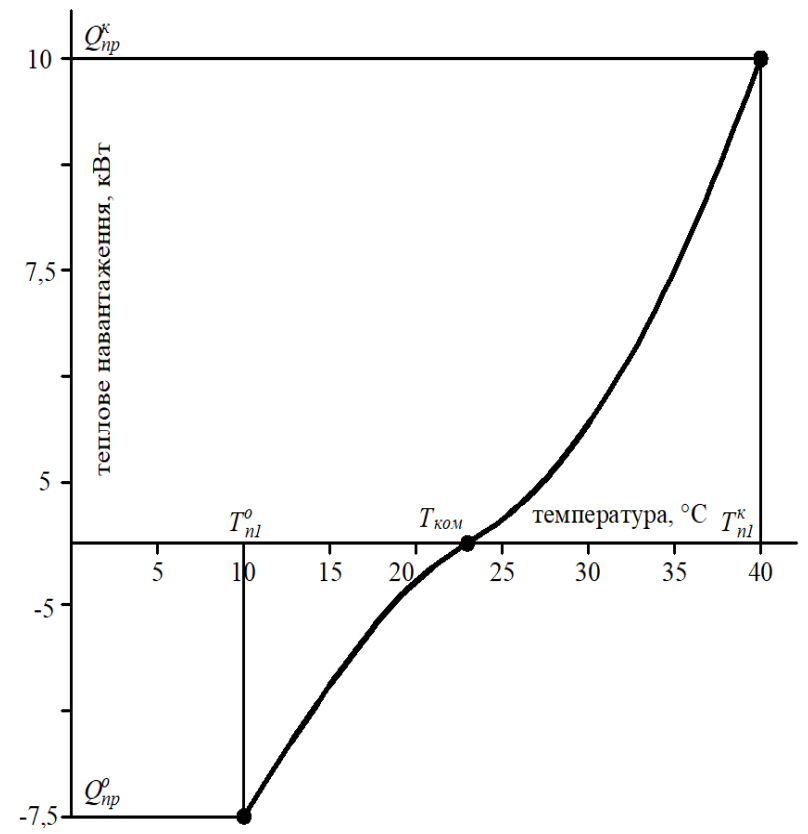

Рисунок 8 - Теплове навантаження на приміщення в залежності від температури навколишнього повітря 
При об’єднанні в інтегровану систему усі харатеристики припиняють бути незалежними і змінюються слідом за аргументами, в залежності від яких вони побудовані.

\section{3. Алгоритм рішення задачі регулювання робо- ти блоку тепло-холодопостачання системи три- генерації}

При стаціонарній роботі машини продуктивності компресора $Q_{o}$ і повітроохолоджувача $Q_{o}^{n o}$ однакові, конденсатора $Q_{\kappa}^{\kappa \dot{ }}$ - строго їм відповідають.

При постійній температурі в житловому приміщенні $T_{\text {ком }}$ режим роботи холодильної машини змінюється в залежності від теплового навантаження на приміщення $Q_{n p}$. При цьому порушується відповідність між продуктивністю компресора, конденсатора і повітроохолоджувача.

Завдання регулювання - повернути машину в стан рівноваги. Її виконує комп'ютерна техніка зі спеціальним програмним забезпеченням.

В даному розділі на окремому прикладі розглядається принцип регулювання роботи блоку теплохолодопостачання і в графічній формі представляється алгоритм вирішення задачі регулювання.

Для аналізу характеристик елементів у складі повної холодильної машини їх представляють в графічній формі в єдиній системі координат $Q-T$. Точки перетину кривих $є$ робочими точками, які позначають рівновагу в роботі елементів.

Комплекс «компресор - повітроохолоджувач» досягає рівноваги (рисунок 9) при рівності $Q_{o}=Q_{o}^{n o}$ або

$$
V_{h} \lambda q_{o} / v_{B c}=k_{i}^{n o} F_{i}^{n o} \theta_{m}^{n o},
$$

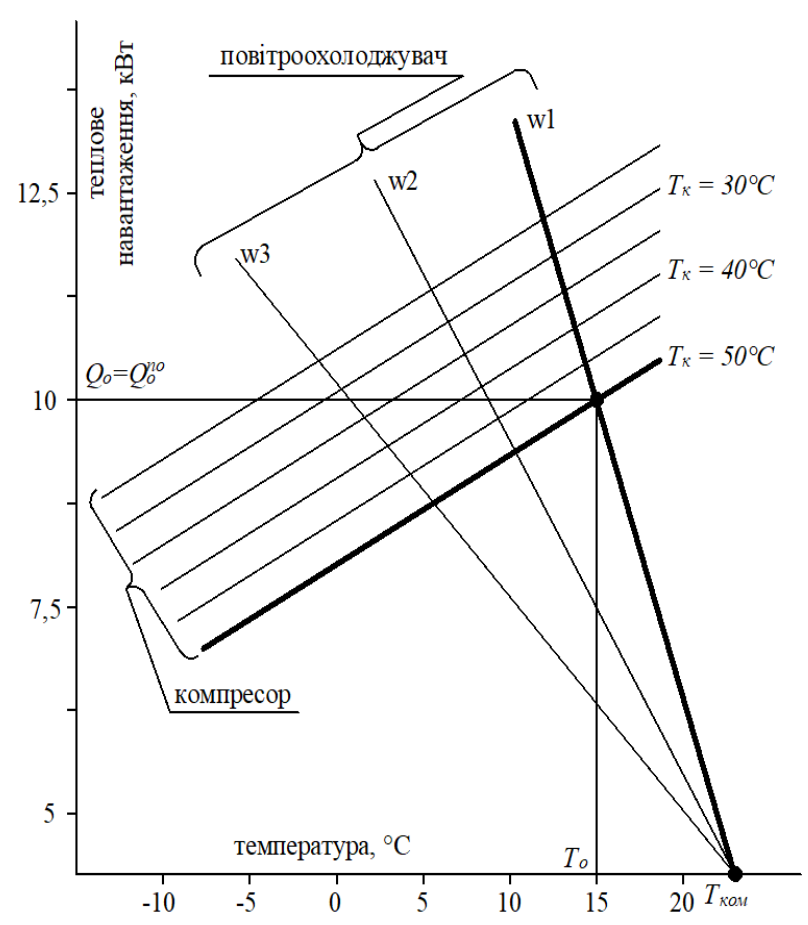

Рисунок 9 - Характеристика комплексу «компресор-повітроохолоджувач»
Комплекс «компресор - конденсатор» досягає рівноваги (рисунок 10) за рівністю

$$
\begin{aligned}
& Q_{\kappa}=Q_{\kappa}^{\kappa \partial} \text { або } \\
& V_{h} \lambda q_{\kappa} / v_{B c}=k_{i}^{\kappa d} F_{i}^{\kappa d} \theta_{m}^{\kappa \partial} \text {, }
\end{aligned}
$$

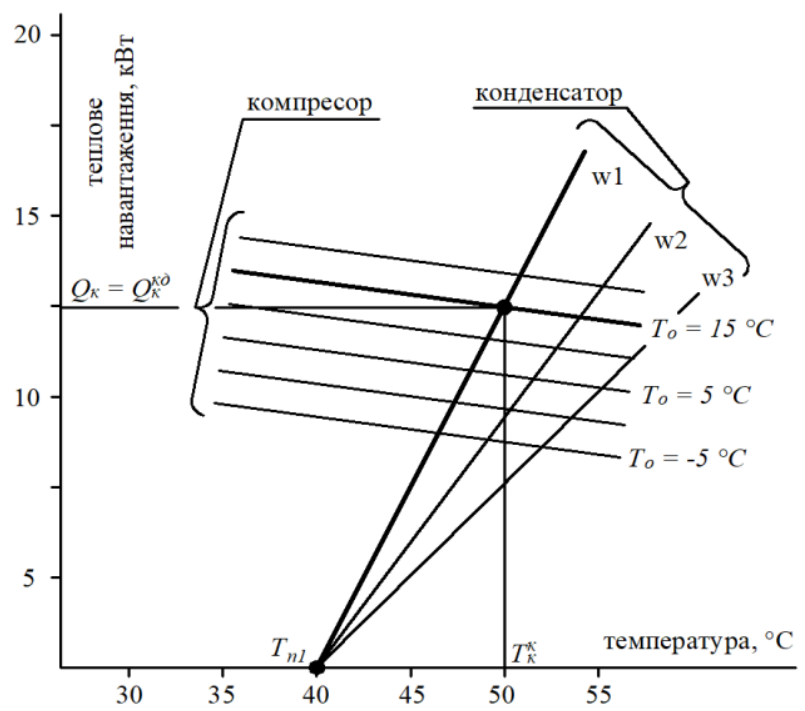

Рисунок 10 - Характеристики комплексу «компресор-конденсатор».

Робота блоку «холодильна машина - приміщення» в режимі кондиціювання досягає рівноваги за умови $Q_{o}=Q_{o}^{n o}=Q_{n p}^{\kappa} \quad$ і в графічному вигляді надана на рисунку 11 .

Розрахунковий режим роботи системи визначається точками: A1 - для приміщення, В1 - для повітроохолоджувача, C1 - для компресора, Д1 - для конденсатора. Режим характеризується: розрахунковою температурою навколишнього повітря $T^{\kappa}{ }_{n 1}=40^{\circ} \mathrm{C}$, максимальною температурою конденсації $T^{\kappa}{ }_{\kappa}=50^{\circ} \mathrm{C}$, температурою кипіння $T_{0}^{\kappa}=15^{\circ} \mathrm{C}$ комфортною температурою в приміщенні $T_{\text {ком }}=23^{\circ} \mathrm{C}$, максимальними теплоприпливами в приміщення $Q_{n p}^{\kappa}=10,0$ кВт, відповідною холодопродуктивністю компресора $Q_{o}=10,6$ кВт повітроохолоджувача $-Q_{o}^{n o}=10,0$ кВт. та тепловим навантаженням на конденсатор $Q_{\kappa}^{\kappa}=12,5$ кВт.

За зниженням теплоприпливів в приміщення до $Q_{n p}^{\kappa}=7,5$ кВт, пов'язаним зі зниженням температури навколишнього повітря до $T^{\kappa}{ }_{n 1}=35^{\circ} \mathrm{C}$ (точка А2) рівновагу в системі порушено. Температура конденсації знижується до $T^{\kappa}{ }_{\kappa}=45^{\circ} \mathrm{C}$, що призводить до зростання холодопродуктивності машини до $Q_{o}=10,6$ кВт (точка C3). Спостерігається невідповідність продуктивностей компресора та повітроохолоджувача.

Для досягнення рівноваги з приміщенням потрібно зменшити холодопродуктивність повітроохолоджувача (точка В2), шляхом зменшення швидкості повітря $w_{1}>w_{2}$. Регулювання швидкості забезпечується зміною витрати повітря, що здійснюється за допомогою інвертора на двигуні вентилятора або жалюзі, які встановлені в припливній лінії вентиляції. 


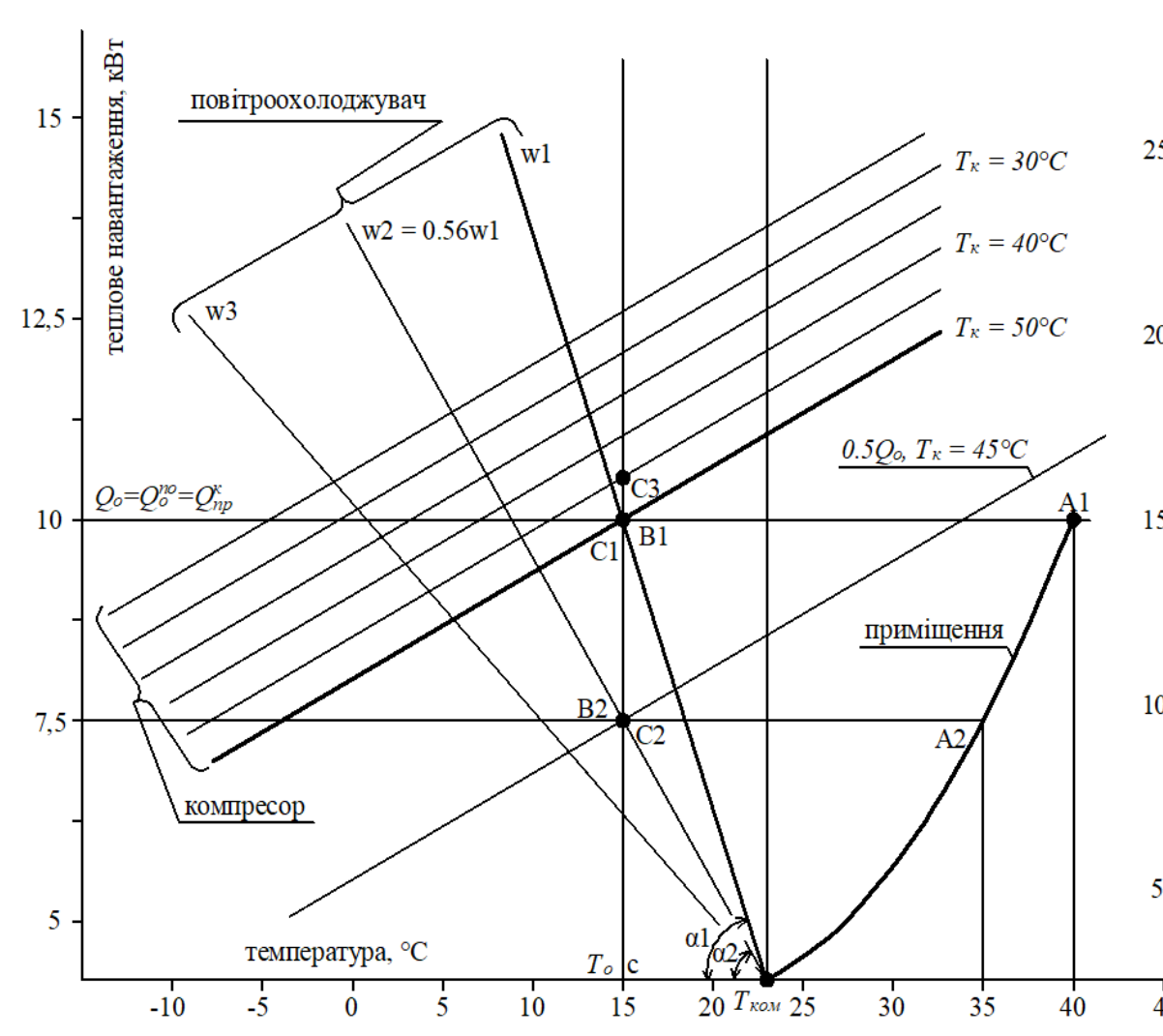

a)

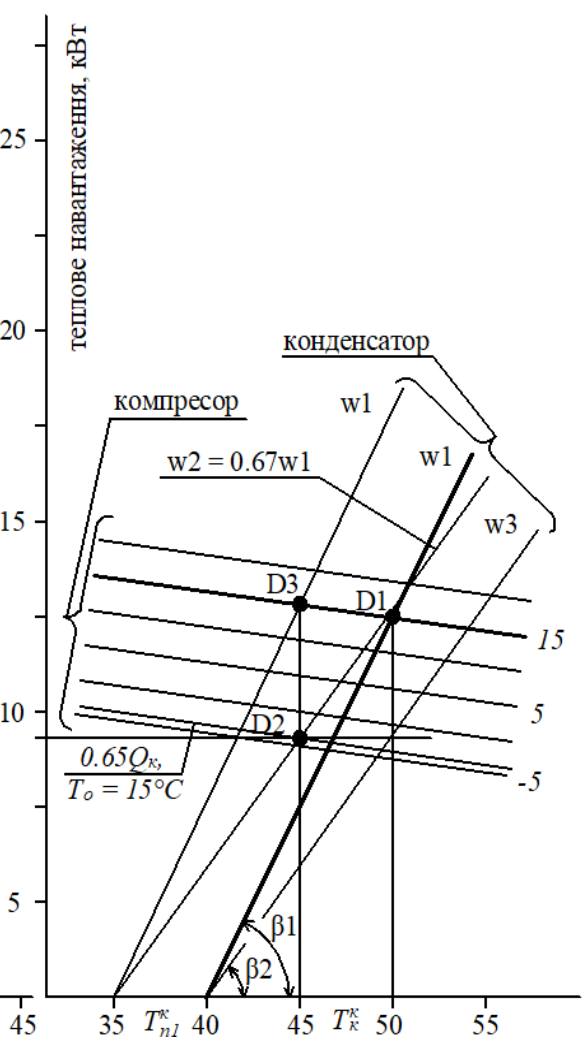

б)

Рисунок 11 - Характеристики блоку «холодильна машина - приміщення» в режимі кондиціювання повітря: а) комплекс «приміщення - повітроохолоджувач - компресор», б) комплекс «компресор - конденсатор»

Для досягнення повної рівноваги системи при стабільній температурі кипіння та зниженні температури конденсації необхідно зменшити холодопродуктивність компресора (точка С2). Сучасним способом регулювання продуктивності компресора $є$ установка електродвигуна з інвертором. Точка С2 відповідає режиму роботи компресора з $0,5 Q_{o}=7,5$, кВт при $T^{\kappa}=15^{\circ} \mathrm{C}$ та $T^{\kappa}{ }_{k}=45^{\circ} \mathrm{C}$. Долю холодопродуктивності компресора встановлено в координатах діаграми відношенням ординат точок $(\mathrm{C} 2 \mathrm{c} / \mathrm{C} 3 \mathrm{c})$.

Конденсатор в режимі кондиціювання охолоджується свіжим повітрям, його відповідність режиму визначено точкою D1. Збільшення продуктивності за зниженням температури зовнішнього повітря, пов'язаної з постійною швидкістю повітря, виводить конденсатор з рівноваги. Повернення до стабільної роботи потребує регулювання витрати повітря шляхом зниження його швидкості, аналогічно до повітроохолоджувача.

Робота блоку «холодильна машина - приміщення» в режимі опалення досягає рівноваги за умови $Q_{\kappa}=Q_{\kappa}^{\kappa \partial}=Q_{n p}^{o}$. Розрахунковий режим роботи системи визначається точками: A1 - для приміщення, В1 - для повітроохолоджувача, С1 - для компресора, Д1 - для конденсатора. Для аналізу: температура навколишнього повітря $T_{n 1}^{0}=10^{\circ} \mathrm{C}$, мінімальна температура конденсації $T^{0}{ }_{k}=30^{\circ} \mathrm{C}$, , комфортною температурою в приміщенні $T_{\text {ком }}=23{ }^{\circ} \mathrm{C}$ максимальні тепловтрати 3 примі- щення $Q_{n p}^{o}=7,5$ кВт, відповідна теплопродуктивність (теплове навантаження на конденсатор) $Q_{k}^{\kappa d}=7,5$ кBт, холодопродуктивність компресора $Q_{o}=6,75$ кВт, холодопродуктивність повітроохолоджувача $Q_{o}^{n o}=6,75$ кВт.

Рішення задачі в графічному вигляді надано на рисунку 12.

Для аналізу введено додаткові умовності. Характеристику приміщення (тепловтрати) як функцію зображено в системі координат за абсолютною величиною, що зробить доступними і наочними усі подальші побудови. За зниженням тепловтрат в приміщення, пов'язаним з підвищенням температури навколишнього повітря (точка А2), знижується температура конденсації і холодопродуктивність компресора зростає (точка B3). Для повернення рівноваги в систему необхідно регулювати теплове навантаження на конденсатор. (точка Д2), характеристики компресора (точка В2) та повітроохолоджувача (точка С2). Витратна характеристика дросельного пристрою також повинна змінитися та прийняти нове значення.

Перехід з режиму кондиціювання в режим опалення здійснюється автоматично перемиканням напрямку руху повітря всередині системи вентиляції. Плавне регулювання продуктивності холодильної машини, яке пропонується, можливе в системах малої теплової інерції або за швидко змінним тепловим навантаженням, що має безпосереднє відношення до досліджуваної системи. 


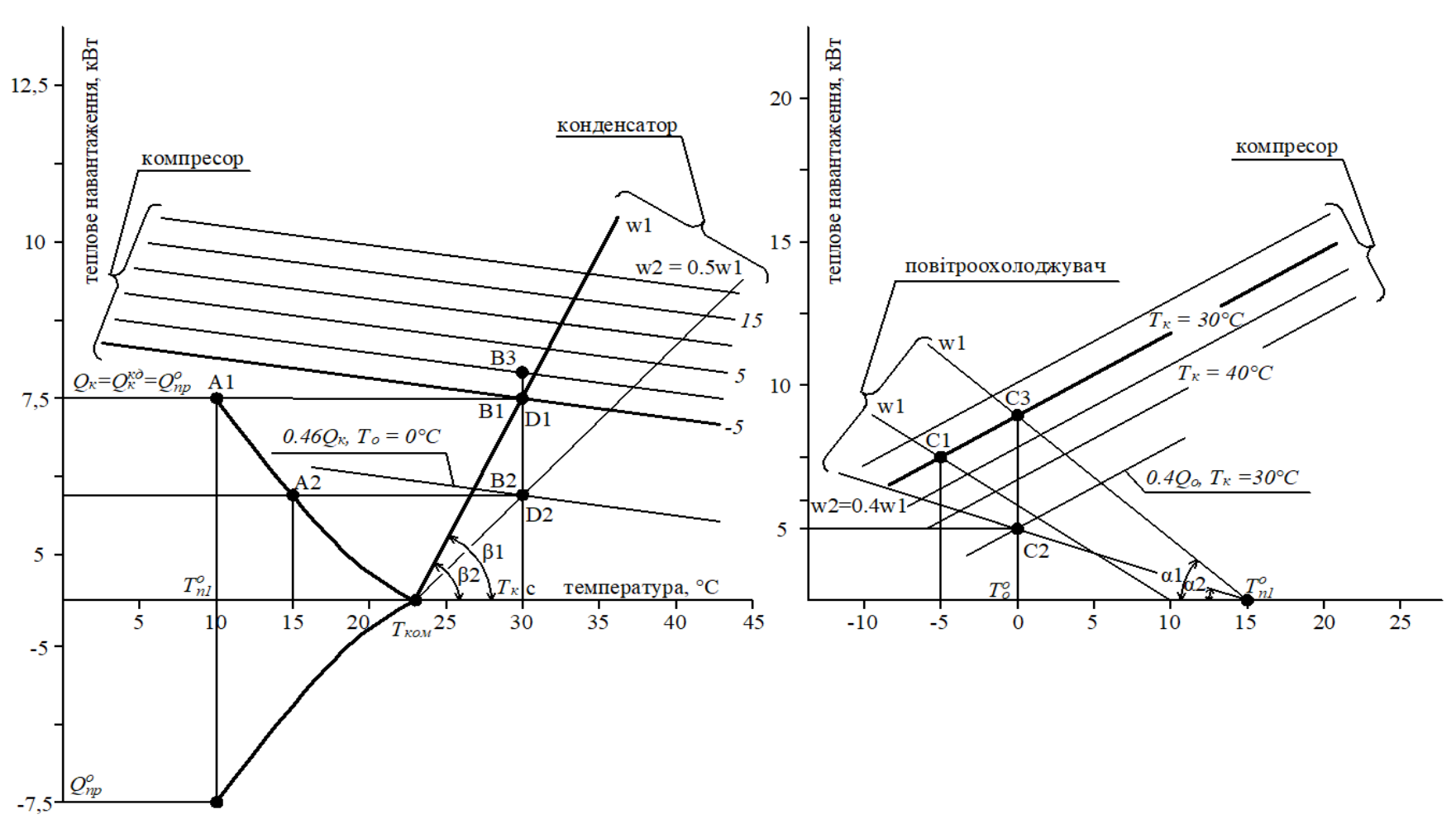

Рисунок 12 - Характеристики блоку «холодильна машина - приміщення» в режимі опалення:

а) комплекс «приміщення - конденсатор - компресор», б) комплекс «компресор - повітроохолоджувач»

Розрахункові теоретичні об’ємні продуктивності компресора та вентилятора встановлюють на підставі теплових розрахунків циклів в режимі кондиціювання та опалення. Для аналізу використовують найбільші значення.

\section{4. Обговорення результатів дослідження}

При аналізі характеристик елементів малої системи тригенерації для тропічного клімату, що ілюструють отримані результати, забезпечення тепло- холодопостачання від однієї компресорної холодильної машини базується на наявності сонячної енергетичної установки 3 прямим перетворенням енергії. Кліматичні умови територій та умови життєдіяльності населення, для яких проектується мала система тригенерації, повинні забезпечувати цілорічне постійне споживання холоду та тепла. Подавання свіжого обробленого повітря в приміщення через теплообмінні апарати холодильної машини та активну вентиляцію від єдиного вентилятора спрощує регулювання характеристик системи, що сприяє енергозбереженню та покращенню екологічного стану приміщння.

Дослідження можна віднести до перспективних проектів, які включають використання інформаційних технологій, і розглядаються авторами як один з напрямів розвитку малих систем тригенерації.

\section{Висновки}

1. Проведеними дослідженнями встановлено, що система тригенерації, яка включає автономну фотоелектричну установку, компресорну холодильну машину та систему активної вентиляції, здатна задовольнити приватних споживачів цілорічним отриманням елект- роенергії, кондиціюванням та опаленням приміщень в залежності від сезонних та добових коливань температури навколишнього повітря на засадах енергозбереження та екологічної безпеки.

2. Особливості регулювання роботи системи тепло- холодопостачання, що містить холодильну машину та систему активної вентиляції, полягають у тому, що електродвигуни компресора та вентилятора мають інвертори, що забезпечує економію енергетичних ресурсів в системі при зміні температури навколишнього повітря за будь-яких умов.

3. Дослідження дозволяє стверджувати, що системи тригенерації малої енергетики із сонячними фотоелектричними станціями здатні вирішувати енергетичні, екологічні та соціальні проблеми населення, що проживає на територіях в умовах тропічного та різко континентального клімату.

\section{Література}

1. Performance assessment of cogeneration and trigeneration systems for small scale applications. Angrisani G., Akisawa A., Marrasso E.et al. - Elsevier. - 2016.

2. Bellos E. Parametric analysis and optimization of a solar driven trigeneration system based on ORC and absorption heat pump / E. Bellos, C. Tzivanidis // International Journal of Refrigeration. - 2017. - Vol.161 - P. 493-509

3. Bilgili, M. , 2011. Hourly simulation and performance of solar electric-vapor compression refrigeration system. Sol. Energy. 85, 2720-2731 .

4.Medved D. Trigeneration units / D. Medved // Intensive Programme "Renewable Energy Sources". - 2011. - P.4750.Available at:http://home.zcu.cz/ tesarova/IP/ Proceedings/Proc_2011/Files/Medved.pdf

5. Fong, K.F., Lee, C.K., Chow, T.T., Lin, Z., Chan, L.S. 
Solarhybrid air-conditioning system for high temperature cooling in subtropical city. Renew Energ. 35, 2010. 2439-2451.

6. RETScreen Plus Expert "Renewable Energy Project Analysis Software, Energy Model and Solar Resource and Heating Load Calculation" (SR\&HLC)// RETScreen Customer Support, CanMet Energy Diversification Research Laboratory, Natural Resources Canada.2018. [Электронный ресурс]:- Режим доступа: https://www.nrcan.gc.ca/energy/resources, https://www. nrcan.gc.ca/energy/efficiency

7. А.С. Денисова, Л.І. Морозюк, Альхемірі Саад Альдін, А.В. Цуркан. Схемно-конструктивні та технологічні особливості систем тригенерації для умов Близького
Сходу //Вісник національного технічного університету "Харківський політехнічний інститут". Серія "Інноваційні дослідження у наукових роботах студентів", 2018, №40 (1316). - C. 10-16. DOI:10.20998/2220-4784.2018. 40.02

8. Морозюк Т. В. Теория холодильных машин и тепловых насосов / Т. В. Морозюк. - Одесса: Студия «Негоциант», 2006. $-712 \mathrm{c}$.

9. Строй А.Ф. Расчет и проектирование систем вентиляции и кондиционирования воздуха / А.Ф. Строй, В.В. Колодяжный. - Киев: Издательство «Феникс», 2014. -343 c.

Отримана в редакції 01.11.2018, прийнята до друку 04.12.2018

\title{
Characteristics and principles of regulation of components within a small trigeneration system for tropical climate conditions
}

\author{
Alla Denysova ${ }^{1}$, Larisa Morozyuk ${ }^{2}$, Alhemiri Saad Aldin ${ }^{1}$, Ganna Luzhanska ${ }^{1}$ \\ ${ }^{1}$ Odessa national polytechnic university, 1 Shevchenko av., Odessa, 65044, Ukraine \\ ${ }^{2}$ Odessa National Academy of Food Technologies, 112 Kanatnaia str., Odessa, 65039, Ukraine
}

\begin{abstract}
The aim of this study is to evaluate the characteristics and algorithm of regulation of elementers within a small trigeneration system. Such a system is capable to provide the private consumers with year-round stable electricity supply, air-conditioning and heating, depending on seasonal and daily ambient temperature fluctuations in tropical climate conditions. The system includes a power generation block with direct conversion of solar energy to electricity, a refrigeration compression machine for air conditioning and space heating as well as active ventilation system. The supply of ambient air (that is processed in the heat exchangers of refrigeration compressoring machine) into the bulding through active ventilation with a single fan simplifies the regulation of the system characteristics, that leads to an improve in the ecological condition of the bulding and in saving of energy. The features of regulation of the heat-and cold-supply system are the following: the electric motors of the compressor and the fan have inverters, which based on software settings, change the capacity of these elements. That provides constant comfortable temperature of room air independent of ambient air temperature fluctuations while saving energy resources within the system. The study showed that such small-scale trigeneration systems are enable to solve the energetic, ecological and social problems of the population living in areas of tropical and drastically continental climate.
\end{abstract}

Keywords: trigeneration, compression refrigeration machine, air conditioning, heating, system regulation, tropical climate.

\section{References}

1. Performance assessment of cogeneration and trigeneration systems for small scale applications / Angrisani G., Akisawa A., Marrasso E.et al. Elsevier, 2016.

2. Bellos E. (2017). Parametric analysis and optimization of a solar driven trigeneration system based on ORC and absorption heat pump / E. Bellos, C. Tzivanidis // International Journal of Refrigeration, vol.161, p. 493-509.

3. Bilgili, M. (2011). Hourly simulation and performance of solar electric-vapor compression refrigeration system. Sol. Energy, 85, 2720-2731.

4. Medved D. (2011). Trigeneration units / D. Medved // Intensive Programme "Renewable Energy Sources", P. 47-50. Available at:http://home.zcu.cz/ tesarova/IP/ Proceedings/Proc_2011/Files/Medved.pdf

5. Fong, K.F., Lee, C.K., Chow, T.T., Lin, Z., Chan, L.S. (2010). Solarhybrid air-conditioning system for high temperature cooling in subtropical city. Renew Energ., 35, 2439-2451.

10. RETScreen Plus Expert "Renewable Energy Project Analysis Software, Energy Model and Solar Resource and
Heating Load Calculation" (SR\&HLC)// RETScreen Customer Support, CanMet Energy Diversification Research Laboratory, Natural Resources Canada. 2018. https://www.nrcan.gc.ca/energy/resources, https://www.nrc an.gc.ca/energy/efficiency

11. Denisova A.E., Morozyuk L.I., AlhemIrI Saad AldIn, Tsurkan A.V. (2018). Shemno-konstruktivnI ta tehnologIchnI osoblivostI sistem trigeneratsIYi dlya umov Blizkogo Shodu. VIsnik natsIonalnogo tehnIchnogo unIversitetu "HarkIvskiy polItehnIchniy Institut". SerIya "InnovatsIynI doslIdzhennya u naukovih robotah studentIv", No.40 (1316), 10-16.DOI: 10.20998/2220-4784.2018.40.02 12. Morozyuk T.V. (2006). Teoriya holodilnyih mashin i teplovyih nasosov. Odessa: Studiya «Negotsiant», 712 p.

13. Stroy A.F., Kolodyazhnyiy V.V. (2014). Raschet i proe-ktirovanie sistem ventilyatsii i konditsionirovaniya vozduha. Kiev: Izdatelstvo «Feniks», 343 p.

Received 01 November 2018 Approved 04 December 2018 Available in Internet 30 December 2018 